\title{
TEKNIK COOPERATIVE INTEGRATED READING AND COMPOSITION (CIRC) UNTUK MENINGKATKAN KEMAMPUAN MENULIS
}

\author{
Cooperative Integrated Reading and Composition Technique (CIRC) \\ to Increase the Writing Ability
}

Achril Zalmansyah

Kantor Bahasa Provinsi Lampung

zzalmansa@gmail.com

\begin{abstract}
Abstrak
Kemampuan siswa dalam menulis narasi sangat rendah sehingga perlunya suatu teknik pembelajaran yang sesuai untuk meningkatkan kemampuan ini. Oleh karena itu, teknik Cooperative Integrated Reading and Composition (CIRC) dapat digunakan sebagai salah satu solusi yang tepat untuk meningkatkan keterampilan ini. Adapun metode yang digunakan dalam penelitian ini adalah deskriptif kualitatif berupa penelitian tindakan kelas. Penelitian dilaksanakan di SMP Negeri 3 Natar Lampung Selatan dengan objek penelitian siswa kelas VII/F. Prosedur penelitian ini dilaksanakan sebanyak tiga siklus, yaitu siklus perencanaan, tindakan dan obsevasi, dan refleksi. Hasil penelitiannya diperoleh (1) Rencana pelaksanaan pembelajaran melalui teknik CIRC dapat meningkatan kemampuan menulis narasi; (2) Proses pembelajaran dalam meningkatkan kemampuan menulis dengan teknik CIRC dapat meningkatkan aktivitas siswa dan guru. Aktivitas siswa di kelas VII/F pada siklus satu mendapat skor 74,24 ; siklus dua mendapat skor 75,30; dan siklus tiga mendapat skor 81,014. Sementara itu, aktivitas guru dalam pembelajaran siklus satu mendapat skor 76, siklus dua 79, dan siklus tiga mendapat skor 82 . Ketuntasan belajar pada siklus satu $65 \%$, siklus dua $73,68 \%$, dan siklus tiga $81 \%$. Nilai kemampuan menulis narasi mengalami peningkatan dari siklus satu ke siklus dua, dan indikator tercapai pada siklus tiga. Simpulannya adalah teknik CIRC terbukti dapat meningkatkan kemampuan menulis narasi siswa.

Kata Kunci: Bacaan terintegrasi, komposisi, dan siswa
\end{abstract}

\begin{abstract}
The aims of the research is to improve the writing learning process and students' achievement through Cooperative Integrated Reading and Composition (CIRC) technique. The method of the research is qualitative descriptive by means of classroom action research. This research is conducted at SMP Negeri 3 Natar Lampung Selatan, and the object of the research is class VII/F. The research procedure consists of three cycles, namely planning, implementation, observation and reflection. The result of this research shows that (1) the lessons planned using CIRC technique are able to increase narrative writing ability and (2) learning process in improving writing ability through
\end{abstract}


CIRC technique could increase students' and teacher's activity. The students' activity in class VII/F scores 72,947 at the first cycle, scores 73,684 at the second and scores 76,71 at the third. Meanwhile, the teachers' activity in learning scores 76 at first cycle, scores 79 at the second cycle and scores 82 at the third. Standard of study at the first cycle is $65 \%, 73,68 \%$ at the second cycle and $82 \%$ at the third. Score of narrative writing ability increases from the first cycle to second cycle, and the indicator is achieved at the third cycle. It is concluded that this technique could increase the students' narrative writing ability.

Keywords: integrated reading, composition, and students

How to Cite: Zalmansyah, Achril. (2018). Teknik Cooperative Integrated Reading and Composition (Circ) untuk Meningkatkan Kemampuan Menulis, Ranah: Jurnal Kajian Bahasa, 7 (2), 229-246. doi: https://doi.org/10.26499/rnh.v7i2.573

\section{PENDAHULUAN}

Salah satu standar kompetensi adalah mengungkapkan berbagai informasi dalam bentuk narasi dan pesan singkat. Dengan kompetensi dasar mengungkapkan pengalaman menjadi narasi dengan memperhatikan cara penulisan kalimat efektif dan sesuai dengan EYD. Pengamatan peneliti sebagai tenaga pendidik menunjukkan bahwa sebagian besar siswa sekolah menengah pertama rata-rata belum mampu mengembangkan kemampuan berkomunikasi bahasa Indonesia, khususnya di dalam keterampilan menulis. Proses pembelajaran keterampilan menulis yang belum efektif juga ditengarai menimbulkan kejenuhan siswa di dalam pembelajaran di kelas.

Dalam pembelajaran guru menggunakan pendekatan konvensional sehingga dari waktu ke waktu pembelajaran terasa membosankan. Siswa tidak tertarik untuk belajar, tidak termotivasi, dan merasa tidak semangat untuk belajar bahasa Indonesia. Situasi seperti ini terjadi di sekolah, tempat penelitian ini dilakukan di mana dari satu kelas yang diamati, dengan jumlah siswa 38 anak, diketahui bahwa pada aspek menulisnya, siswa yang tidak tuntas berjumlah 26 anak, sedangkan siswa yang mencapai ketuntasan belajar 12 anak dari Kemampuan Ketuntasan Minimal (KKM) yang telah ditentukan, yaitu 67.

Secara khusus, (Slavin, 2005: 200) menyebutkan kelebihan teknik pembelajaran Cooperative Integrated Reading and Composition (CIRC) sebagai berikut.

a) teknik CIRC sangat tepat untuk mengatasi masalah tradisional dalam pengajaran pelajaran membaca, menulis, dan seni berbahasa; b) dominasi guru dalam pembelajaran berkurang; c) siswa termotivasi pada hasil secara teliti karena bekerja dalam kelompok; 
d) para siswa dapat memahami makna kata dan saling mengecek pekerjaan teman dalam kelompoknya; e) membantu siswa yang lemah; dan f) meningkatkan hasil belajar khususnya dalam merencanakan, merevisi dan menyunting karangan mereka dengan kolaborasi.

Selanjutnya, unsur utama dari teknik CIRC adalah 1) kelompok membaca; 2) kegiatan-kegiatan yang berhubungan dengan cerita; 3) membaca berpasangan; 4) menulis cerita yang bersangkutan dan tata bahasa cerita; 5) mengucapkan kata-kata dengan keras; 6) makana kata; 7) menceritakan kembali cerita; 8) pemeriksaan oleh pasangan; dan 9) seni berbahasa dan menulis terintegrasi (Slavin, 2005: 209).

Peneliti berpendapat bahwa di dalam upaya meningkatkan kemampuan siswa di dalam menulis narasi perlu dilakukan terobosan untuk meningkatkan pembelajaran tersebut. Untuk itulah peneliti meyakini dengan menggunakan teknik Cooperative Integrated Reading and Composition (CIRC) diharapkan kemampuan siswa di dalam penulisan narasi meningkat. Penelitian dengan menggunakan teknik CIRC ini dilakukan pada kelas VII. Dengan menggunakan teknik ini, diharapkan para siswa dapat belajar secara aktif, kreatif, dan senang.

\section{LANDASAN TEORI}

Menulis merupakan salah satu keterampilan berbahasa dengan penggunaan bahasa secara tertulis. Dalam kegiatan menulis, penulis harus terampil menggunakan, grafologi, struktur bahasa, kosakata (Tarigan, 1998: 4). Menurut Suparno dan Yunus (2003: 13) bahwa aktivitas menulis melibatkan beberapa unsur, yaitu penulis sebagai penyampaian pesan, isi tulisan, saluran atau media, dan pembaca. Menulis merupakan suatu kegiatan penyampaian pesan (komunikasi) dengan menggunakan bahasa tulis sebagai alat atau medianya. Sementara itu, Dalman (2012: 3) berpendapat bahwa menulis merupakan suatu kegiatan komunikasi berupa penyampaian pesan (informasi) secara tertulis kepada pihak lain dengan menggunakan bahasa tulis atau medianya. Sejalan dengan pendapat Akhadiah (1997) dapat juga diartikan bahwa menulis adalah berkomunikasi mengungkapkan pikiran, perasaan, dan kehendak kepada orang lain secara tertulis.

Slamet dalam Apriyanti (2010: 20) menyatakan bahwa menulis merupakan kegiatan menggali pikiran dan perasaan mengenai suatu subjek, memilih hal-hal yang akan ditulis, menentukan cara menuliskannya sehingga pembaca dapat memahaminya 
dengan mudah dan jelas. Pada dasarnya menulis itu bukan hanya melahirkan pikiran atau perasaan saja, melainkan juga merupakan mengungkapkan ide-ide, pengetahuan, ilmu, dan pengalaman hidup seseorang dalam bahasa tulis. Menurut Rusyana (1994), menulis adalah kemampuan menggunakan pola-pola bahasa dalam penampilannya secara tertulis untuk mengungkapkan suatu gagasan atau pesan. Sementara itu, pendapat pakar lain yang mengatakan bahwa menulis merupakan sebuah proses kreatif menuangkan gagasan dalam bentuk bahasa, misalnya memberi tahu, meyakinkan atau menghibur. Menulis lazimnya sebuah tulisan dihasilkan melalui suatu proses, dari perencanaan, penulisan, penyuntingan (pengeditan) hingga perevisian (Kalidjernih, 2010: 5)

Berdasarkan pendapat para pakar, dapat disimpulkan bahwa menulis adalah suatu proses untuk menyampaikan pikiran, angan-angan, perasaan dalam bentuk simbol atau tanda tulisan yang memiliki makna. Dalam kegiatan menulis terdapat suatu kegiatan merangkai, menyusun, melukiskan suatu lambang atau tulisan berupa kumpulan huruf yang membentuk kata, kumpulan kata yang membentuk frasa atau kalimat, kumpulan kalimat yang membentuk paragraf, dan kumpulan paragraf yang membentuk wacana atau karangan yang memiliki makna.

Karangan Narasi (berasal dari naration berarti cerita) adalah suatu bentuk tulisan yang berusaha menciptakan, mengisahkan, dan merangkaikan tindak tanduk perbuatan manusia dalam sebuah peristiwa secara kronologis atau berlangsung dalam suatu kesatuan waktu (Finoza, 2008). Menurut Keraf (2003: 136), bahwa karangan narasi merupakan suatu bentuk karangan yang sasaran utamanya adalah tindak tanduk yang dijalin dan dirangkai menjadi sebuah peristiwa yang terjadi dalam suatu kesatuan waktu. Dalam Kamus Besar Bahasa Indonesia dijelaskan bahwa narasi adalah (1) penceritaan suatu cerita atau kejadian, (2) cerita atau deskripsi dari suatu kejadian. Cerita dapat berupa pengalaman dan pengetahuan penulis (Depdiknas, 1999: 683).

Narasi di dalam pembelajaran bahasa Indonesia di sekolah dapat dijadikan sebagai salah satu bahan ajar di sekolah. Adapun bahan merupakan komponen pembelajaran yang penting yang dapat membantu siswa memahami materi pelajaran dan kompetensi yang harus dicapai siswa. Di dalam kaitannya dengan kompetensi menulis, narasi merupakan salah satu sarana atau alat yang digunakan untuk mengetahui sejauh mana kemampuan siswa di dalam menulis. 
Dari beberapa pendapat dapat disimpulkan narasi merupakan cerita yang berusaha menciptakan, mengisahkan, dan merangkaikan tindak tanduk manusia dalam sebuah peristiwa atau pengalaman manusia dari waktu ke waktu. Di dalamnya terdapat tokoh yang menghadapi suatu konflik yang disusun secara sistematik dan narasi sebagai salah satu cara yang dapat digunakan untuk mengetahui kemampuan menulis siswa.

Pembelajaran Kontekstual/CTL (Contextual Teaching and Learning) merupakan konsep belajar yang dapat membantu guru mengaitkan antara materi yang akan diajarkan dengan situasi dunia nyata siswa dan mendorong siswa membuat hubungan antara pengetahuan yang dimilikinya dengan penerapannya dalam kehidupan mereka sebagai anggota keluarga dan masyarakat (Nurhadi dalam Rusman, 2012: 189).

\section{METODE PENELITIAN}

Penelitian ini dilakukan di kelas VII SMP Negeri 3 Natar, Kabupaten Lampung Selatan tahun pelajaran 2016/2017. Adapun subjek yang terlibat dalam penelitiannya, yaitu siswa pada kelas VII/F yang berjumlah 38 siswa yang terdiri atas 19 laki-laki dan 19 perempuan. Objek penelitiannya adalah penerapan model pembelajaran kontekstual teknik CIRC, sedangkan yang menjadi fokus masalahnya adalah kemampuan menulis narasi siswa rendah.

Sumber data yang dimanfaatkan dalam penelitian ini adalah sebagai berikut.

1) Unsur-unsur proses belajar-mengajar yang terdiri atas. (a) kesiapan belajar siswa; (b) proses belajar-mengajar dengan tujuan untuk memperbaiki proses dan meningkatkan hasil belajar siswa; (c) model pembelajaran kontekstual teknik CIRC; dan (d) portofolio, berupa tugas belajar siswa selama proses pembelajaran.

2) Informasi data dari narasumber yang terdiri atas siswa kelas VII/F dan guru mata pelajaran bahasa Indonesia.

3) Tempat dan peristiwa berlangsungnya kegiatan pembelajaran bahasa Indonesia pada pokok bahasan menulis narasi dengan teknik CIRC (Cooperative Integrated Reading and Composition) atau Teknik Kooperatif Terpadu Membaca dan Menulis.

Teknik yang digunakan dalam mengumpulkan data tersebut meliputi tes dan non-tes, sedangkan alat pengumpul datanya disesuaikan dengan teknik yang dipakai. Teknik tes di dalam penelitian ini adalah dengan menggunakan tes yang biasa dilakukan seorang guru, sedangkan non-tes bisa menggunakan wawacara atau pengamatan terhadap siswa. 
Analisis data pada penelitian tindakan merupakan proses menyeleksi, menyederhanakan, memfokuskan, mengabstraksikan, mengorganisasikan data secara sistematis dan rasional serta menampilkan bahan-bahan yang dapat digunakan untuk menyusun jawaban terhadap tujuan penelitian tindakan kelas. Analisis data yang digunakan dalam penelitian ini adalah analisis wacana dan analisis isi. Penelitian dengan Teknik Analisis Wacana (Discourse Analysis) digunakan untuk untuk menganalisis data yang digunakan baik untuk menganalisis data alamiah maupun data data yang telah dikondisikan dalam perolehannya (Setiyadi, 2006: 264), sedangkan Teknik Analisis Isi (Content Analysis) menurut Setiyadi (2006: 266) bahwa dalam proses analisis data menggunakan analisis isi sangat tepat untuk menganalisis data yang tertulis dan kurang tepat untuk data yang terekam. Analisis Isi (Content Analysis) dimulai dari mengelompokkan data berdasarkan kategori atau tema tertentu, kemudian data tersebut disatukan ke dalam kategori atau tema.

Adapun langkah-langkah yang ditempuh dalam menganalisis data melalui sejumlah tahapan, di antaranya memeriksa hasil kerja atau tulisan siswa berdasarkan aspek yang ditentukan; memberikan skor pada aspek yang diperiksa sesuai dengan penskoran yang telah ditetapkan; merekap data penilaian yang diperoleh siswa untuk setiap aspek yang diteliti; menjumlahkan nilai yang diperoleh siswa pada setiap aspek kemudian mencari nilai rata-ratanya; menghitung siswa yang tuntas KKM; dan menentukan tingkat ketercapaian rata-rata persentase ketuntasan belajar.

\section{HASIL DAN PEMBAHASAN}

\section{Siklus Pembelajaran}

\subsection{Siklus Satu}

\section{A. Perencanaan (Planning)}

Meliputi membuat rencana pelaksanaan pembelajaran (RPP) sesuai dengan silabus yang berisi tujuan pembelajaran, materi pembelajaran, langkah-langkah kegiatan, sumber belajar, dan penilaian.

\section{B. Tindakan (Acting)}

Pada pertemuan ini, langkah-langkah yang ditempuh adalah sebagai berikut.

1. Kegiatan awal

a) Guru membuka pelajaran dengan salam. 
b) Guru mengecek kehadiran siswa satu persatu.

c) Guru mengadakan apersepsi agar wawasan siswa mulai terbangun.

d) Guru menyampaikan kompetensi dasar yang ingin dicapai.

2. Kegiatan inti

a) Guru mengondisikan siswa untuk siap mengikuti pembelajaran.

b) Guru memberikan penjelasan materi menulis narasi secara sekilas, dan cara belajar berkelompok melalui pembelajaran teknik CIRC.

c) Guru memberikan motivasi agar siswa dapat belajar berkelompok secara aktif dan tertib.

d) Guru menugasi masing-masing kelompok untuk mengerjakan tugas yang ditetapkan oleh guru secara bersungguh-sungguh.

e) Guru membagikan lembaran contoh teks narasi dan lembar kerja kelompok.

f) Guru menyuruh siswa membaca teknik narasi dalam secara bergantian.

g) Guru dan teman sejawat mengamati dan mencatat aktivitas dan hasil belajar siswa.

h) Memfasilitasi peserta didik memahami isi teks narasi dan menentukan unsur-unsur intrinsiknya.

i) Memfasilitasi peserta didik untuk menyelesaikan penggalan narasi individual.

3. Kegiatan akhir

a) Guru menyimpulkan hasil pembelajaran.

b) Guru menugasi siswa untuk belajar di rumah serta mempersiapkan diri untuk belajar pada pertemuan berikutnya.

c) Guru menutup kegiatan pembelajaran dengan salam

\section{Observasi (Observating)}

\section{Aktivitas belajar siswa}

Aktivitas siswa dalam proses pembelajaran memahami bacaan narasi melalui teknik CIRC masuk kategori cukup. Perhatikan perolehan data sebagaimana terlihat pada tabel berikut ini.

Tabel 1

Rekapitulasi Data Pengamatan Ativitas Belajar Siklus Satu

\begin{tabular}{llcccc}
\hline \multirow{2}{*}{ No. Ativitas Siswa dalam Pembelajaran } & & $\sum$ Siswa & \multicolumn{3}{c}{ Skor } \\
\cline { 4 - 6 } & & & \multirow{2}{*}{ a } & & c \\
\hline 1 & Siswa tidak datang terlambat & 38 & 37 & - & 1 \\
\hline 2 & Siswa berpakaian rapi & 38 & 31 & - & 7 \\
\hline 3 & Siswa membaca dengan aktif & 38 & 21 & - & 17 \\
\hline 4 & $\begin{array}{l}\text { Siswa berinteraksi dengan teman-teman selama proses } \\
\text { pembelajaran }\end{array}$ & 38 & 9 & 3 & 26 \\
\hline 5 & Siswa mengajukan pertanyaan & 38 & 6 & - & 32 \\
\hline 6 & Siswa berperan aktif dalam pembelajaran & 38 & 6 & 5 & 27 \\
\hline 7 & Siswa memberikan komentar atau pendapat & 38 & 14 & 6 & 18 \\
\hline 8 & Siswa mendiskusikan idenya dengan teman. & 38 & 11 & - & 27 \\
\hline 9 & Siswa mengungkapkan ide-ide dalam pembelajaran & 38 & 18 & 4 & 16 \\
\hline 10 & Siswa mengerjakan tugas tepat waktu & 38 & 29 & 4 & 5 \\
\hline Jumlah & 380 & 182 & 22 & 176 \\
\hline Persentase & $100 \%$ & $47,90 \%$ & $5,79 \%$ & $46,31 \%$ \\
\hline
\end{tabular}

Keterangan: $a=$ Aktif $\quad b=$ Cukup Aktif $\quad c=$ Kurang Aktif 
Persentase hasil tertera pada Tabel 1 dengan rincian kategori 47,90\% aktif, 5,79\% kategori kuranh aktif, dan 46,31\% kategori cukup aktif. Dalam proses pembelajaran menulis narasi aktivitas yang dilakukan oleh guru diperoleh persentase hasil pengamatan masuk kategori baik, yaitu mencapai 76\%, sebagaimana terlihat pada tabel berikut ini.

Tabel 2

Rekapitulasi Pengamatan Aktivitas Guru dalam Proses Pembelajaran Siklus Satu

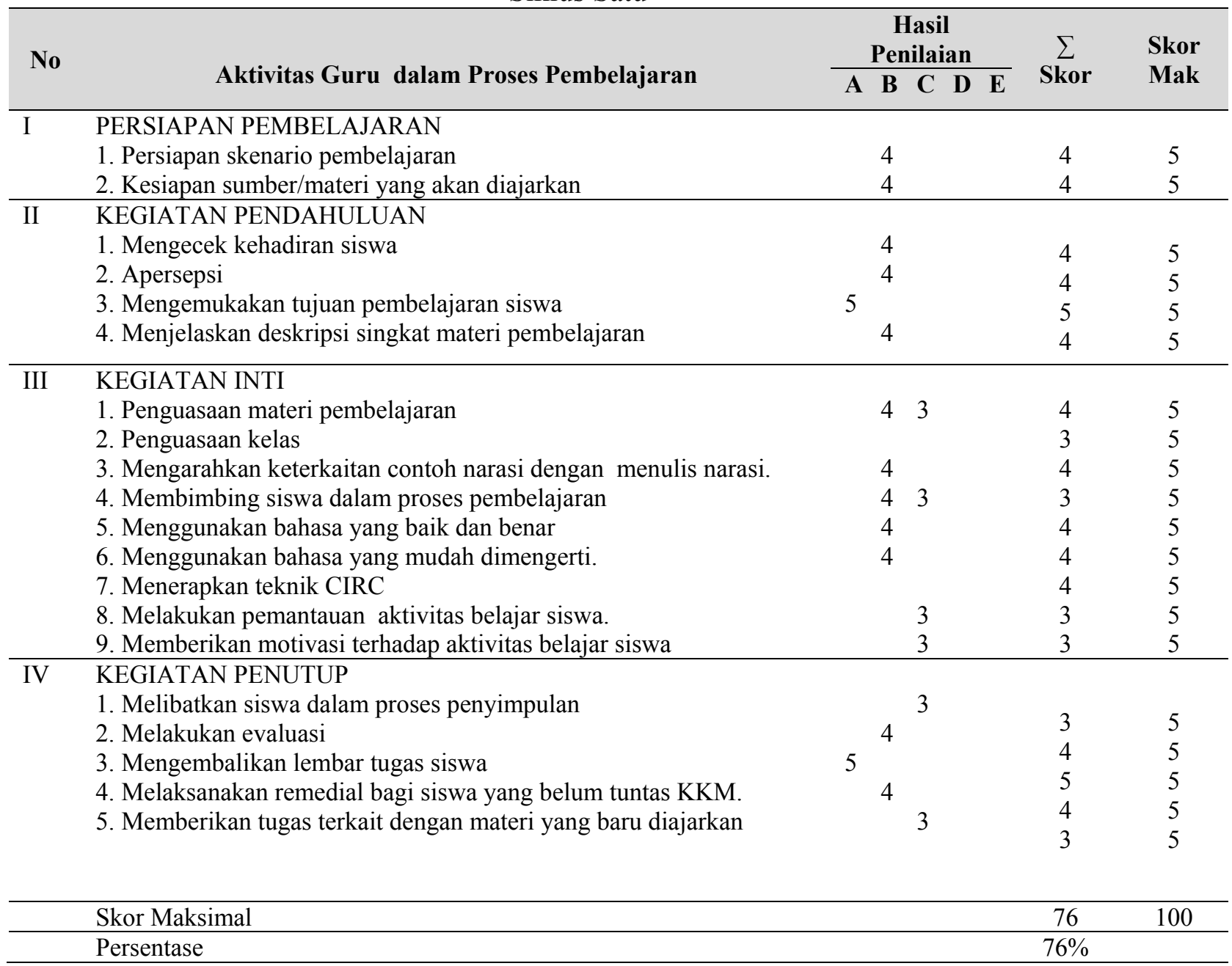

2. Hasil belajar

Hasil penilaian selama proses siklus satu hasilnya siswa mengalami sedikit peningkatan dengan ketercapaian indikator 74,242. Kalau dibandingkan dengan hasil prapenelitian, yaitu $71,63 \%$ meningkat menjadi 74,24\%. Perhatikan data perolehan hasil belajar siswa sebagaimana tabel berikut. 
Tabel 3

Rekapitulasi Hasil Belajar Siswa dalam Memahami Bacaan Narasi - Siklus Satu

\begin{tabular}{|c|c|c|c|}
\hline No & Aspek yang Dinilai & Skor & $\begin{array}{l}\text { Skor } \\
\text { Mak }\end{array}$ \\
\hline 1 & Ketepatan menentukan tema narasi & 8,32 & 10 \\
\hline 2 & Ketepatan menentukan tokoh & 8,61 & 10 \\
\hline 3 & Ketepatan menentukan setting/latar & 8,74 & 10 \\
\hline 4 & Ketepan menentukan alur/plot & 7,11 & 10 \\
\hline 5 & Kalimat utama dan penjelas & 6,53 & 10 \\
\hline 6 & $\begin{array}{l}\text { Ketepatan penyusunan paragraf, kalimat, diksi, bentuk kata, ketepatan } \\
\text { makna }\end{array}$ & 6,26 & 10 \\
\hline 7 & $\begin{array}{l}\text { Ketepatan penggunaan ejaan, kerapian dan tulisan, kejelasan dan ketepatan } \\
\text { penulisan kata }\end{array}$ & 6,52 & 10 \\
\hline & Jumlah skor & 51,97 & 70 \\
\hline & Skor rata-rata & 74,242 & \\
\hline & $\begin{array}{ll}\text { Skor maksimum } & : 100 \\
\text { Perhitungan nilai skala } & : 0--100 \\
\text { Perhitungan nilai Akhir } & =\text { (Skor maksimum/Skor maksimum) } \times 100 \%\end{array}$ & & \\
\hline
\end{tabular}

\subsection{Siklus Dua}

Tahapan selanjutnya dengan melakukan tahapan Siklus Dua sebagai tahapan lanjutan untuk melihat sejauh mana peningkatan yang dilakukan siswa. Tahapan pada siklus dua yang dilakukan hampir sama dengan tahapan siklus satu hanya penekanannya pada yang direkomendasikan pada siklus satu, seperti perencanaan (planning), tindakan (acting), dan observasi (observating).

\section{Aktivitas Belajar Siswa}

Aktivitas siswa dalam proses pembelajaran memahami bacaan narasi melalui teknik Cooperative Integrated Reading and Composition (CIRC) masuk kategori cukup baik $(63,16 \%)$. Untuk lebih jelasnya perhatikan perolehan data pada tabel berikut.

Tabel 4

Rekapitulasi Hasil Pengamatan Aktivitas Belajar Siklus Dua

\begin{tabular}{llcccc}
\hline \multirow{2}{*}{ No. } & & & \multicolumn{3}{c}{ Skor } \\
\cline { 3 - 6 } & & $\sum$ Siswa & \multirow{2}{*}{$\mathbf{a}$} & \multirow{2}{*}{ b } & C \\
\hline 1 & Siswa tidak datang terlambat & 38 & 37 & - & 1 \\
\hline 2 & Siswa berpakaian rapi & 38 & 35 & - & 3 \\
\hline 3 & Siswa membaca dengan aktif & 38 & 30 & 3 & 5 \\
\hline \multirow{2}{*}{4} & $\begin{array}{l}\text { Siswa berinteraksi/diskusi dengan teman-teman selama } \\
\text { pembelajaran }\end{array}$ & 38 & 20 & \multirow{2}{*}{13} & 5 \\
\hline 5 & Siswa mengajukan pertanyaan & 38 & 27 & 6 & 5 \\
\hline 6 & Siswa berperan aktif dalam pembelajaran & 38 & 6 & 5 & 27 \\
\hline 7 & Siswa memberikan komentar & 38 & 14 & 6 & 18 \\
\hline 8 & Siswa mendiskusikan ide dengan temannya & 38 & 21 & 9 & 8 \\
\hline 9 & Siswa mengungkapkan ide-ide dalam pembelajaran. & 38 & 18 & 14 & 6 \\
\hline
\end{tabular}




\begin{tabular}{cccccc}
\hline 10 & Siswa mengerjakan tugas tepat waktu & 38 & 34 & 4 & - \\
\hline Jumlah & 380 & 240 & 60 & 80 \\
\hline Persentase & $\mathbf{1 0 0 \%}$ & $\mathbf{6 3 , 1 \%}$ & $\mathbf{1 5 , 8 \%}$ & $\mathbf{2 1 , 0 5 \%}$ \\
\hline
\end{tabular}

Keterangan: $\mathrm{a}=$ Aktif $\mathrm{b}=$ Cukup Aktif $\mathrm{c}=$ Kurang Aktif

Diperoleh persentase hasil pengamatan sebagaimana tertera pada Tabel 4 di atas dengan rincian 63,16\% kategori aktif, 15,8\% kategori kurang aktif, dan 21,05\% kategori cukup aktif. Selanjutnya, hasil pengamatan proses kerja kelompok pada siklus dua ini diperoleh hasil sebagaimana tertera pada tabel berikut.

Tabel 5

Rekapitulasi Hasil Pengamatan Kerja Kelompok Siklus Dua

\begin{tabular}{cccccc}
\hline \multirow{2}{*}{ No. } & Aspek yang Diamati & $\begin{array}{c}\sum \\
\text { Kelompok }\end{array}$ & Aktif & $\begin{array}{c}\text { Cukup } \\
\text { aktif }\end{array}$ & $\begin{array}{c}\text { Kurang } \\
\text { aktif }\end{array}$ \\
\cline { 5 - 7 } & Kerja sama & 13 & 1 & 8 & 4 \\
\hline 1 & Tanggung jawab & 13 & 2 & 6 & 5 \\
\hline 3 & Keaktifan & 13 & 3 & 6 & 4 \\
\hline 4 & Ketelitian & 13 & 2 & 7 & 4 \\
\hline \multicolumn{2}{r}{ Jumlah } & 52 & 21 & 19 & 12 \\
\hline & Persentase & $100 \%$ & $40,39 \%$ & $36,54 \%$ & $23,07 \%$ \\
\hline
\end{tabular}

Data pada tabel di atas diketahui bahwa persentase hasil pengamatan sebagaimana tertera dengan rincian 40,39\% kategori aktif, 36,54\% kategori cukup aktif, dan 23,07\% kategori kurang aktif. Selanjutnya, hasil pengamatan yang dilakukan oleh kolaborator tentang proses pembelajaran menulis narasi yang dilakukan oleh guru, diperoleh persentase hasil pengamatan masuk kategori baik dengan tingkat ketercapaian 79\%. Perhatikan Tabel 6 berikut ini.

Tabel 6

Rekapitulasi Pengamatan Aktivitas Guru dalam Proses Pembelajaran - Siklus Dua

\begin{tabular}{|c|c|c|c|c|c|c|c|c|}
\hline \multirow[b]{2}{*}{ No } & \multirow[b]{2}{*}{ Aktivitas Guru dalam Proses Pembelajaran } & \multicolumn{5}{|c|}{ Hasil Penilaian } & \multirow{2}{*}{$\sum_{\text {Skor }}^{\sum}$} & \multirow{2}{*}{$\begin{array}{l}\text { Skor } \\
\text { Maks }\end{array}$} \\
\hline & & $\mathrm{A}$ & B & $\mathrm{C}$ & $\mathrm{D}$ & $\mathrm{E}$ & & \\
\hline \multirow[t]{3}{*}{ I } & PERSIAPAN PEMBELAJARAN & & & & & & & \\
\hline & 1. Persiapan skenario pembelajaran. & & 4 & & & & 4 & 5 \\
\hline & $\begin{array}{l}\text { 2. Kesiapan sumber/materi yang akan } \\
\text { diajarkan. }\end{array}$ & & 4 & & & & 4 & 5 \\
\hline \multirow[t]{5}{*}{ II } & KEGIATAN PENDAHULUAN & & & & & & & \\
\hline & 1. Mengecek kehadiran siswa. & & 4 & & & & 4 & 5 \\
\hline & 2. Apersepsi & & & 3 & & & 3 & 5 \\
\hline & 3. Mengemukakan tujuan pembelajaran. & 5 & & & & & 5 & 5 \\
\hline & $\begin{array}{l}\text { 4. Menjelaskan deskripsi singkat materi } \\
\text { pembelajaran. }\end{array}$ & & 4 & & & & 5 & 5 \\
\hline \multirow[t]{4}{*}{ III } & KEGIATAN INTI & & & & & & & \\
\hline & 1. Penguasaan materi pembelajaran & & 4 & & & & 4 & 5 \\
\hline & 2. Penguasaan kelas & & 4 & & & & 4 & 5 \\
\hline & $\begin{array}{l}\text { 3. Mengarahkan keterkaitan contoh } \\
\text { narasi dengan menulis narasi. } \\
\text { 4. Membimbing siswa dalam proses }\end{array}$ & & 4 & & & & 4 & 5 \\
\hline
\end{tabular}




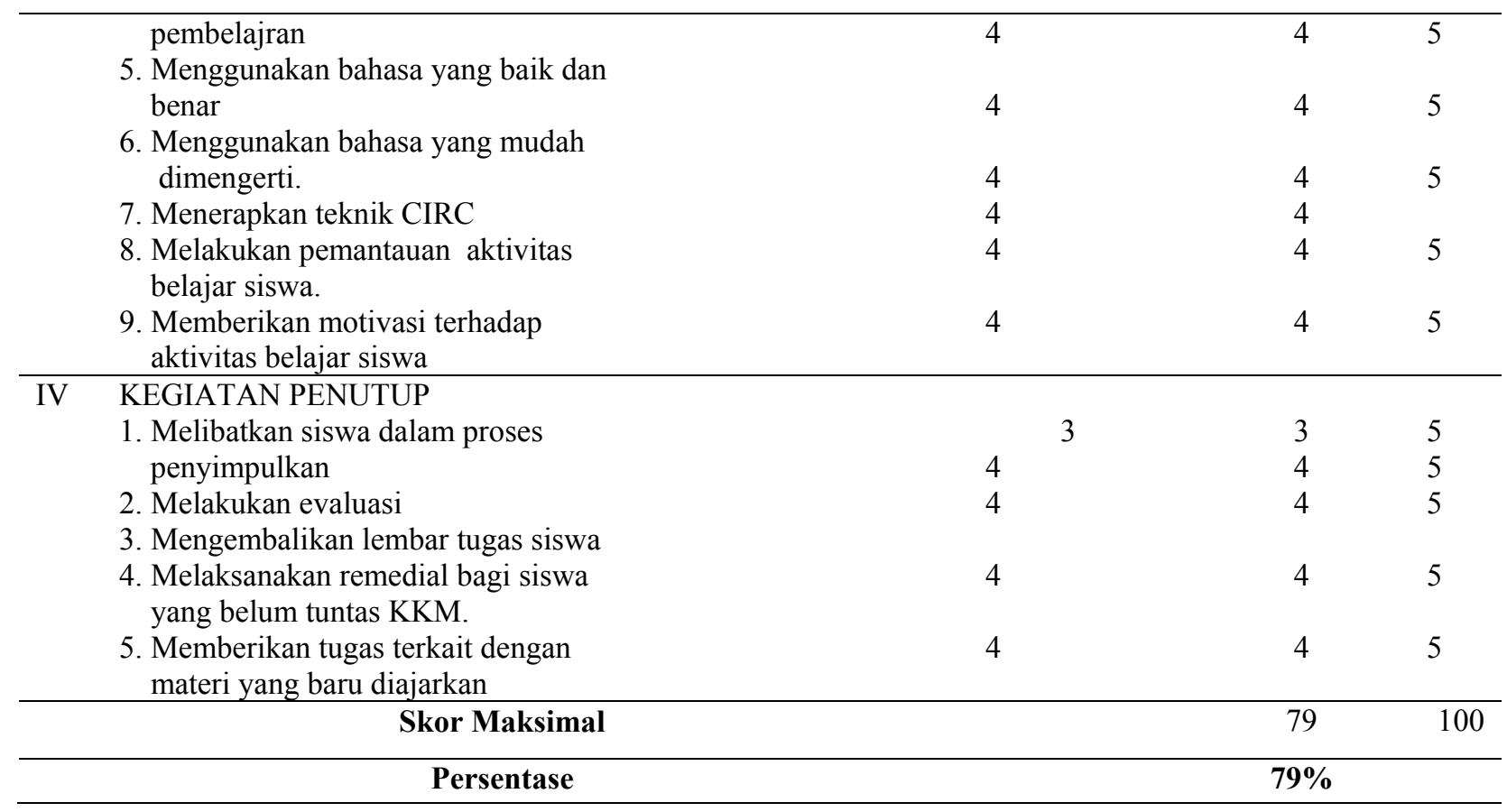

\section{Hasil Belajar Siswa}

Hasil penilaian selama proses pembelajaran pada pertemuan siklus dua (CIRC) telah mengalami peningkatan dengan ketercapaian indikator 75,30. Ini berarti dari persentase telah ada peningkatan jika dibandingkan dengan hasil penelitian pada siklus satu, yaitu 74,24 (lihat Tabel 3) yang meningkat menjadi 75,30 sebagaimana terlihat pada tabel berikut ini.

Tabel 7

Rekapitulasi Hasil Belajar Memahami Bacaan Narasi - Siklus Dua

\begin{tabular}{|c|c|c|c|}
\hline No & Aspek yang Dinilai & Skor & $\begin{array}{l}\text { Skor } \\
\text { Maks }\end{array}$ \\
\hline 1 & Ketepatan menentukan tema narasi & 7,39 & 10 \\
\hline 2 & Ketepatan menentukan tokoh & 7,79 & 10 \\
\hline 3 & Ketepatan menentukan setting/latar & 7,82 & 10 \\
\hline 4 & Ketepan menentukan alur/plot & 7,18 & 10 \\
\hline 5 & Kalimat utama dan penjelas & 7,53 & 10 \\
\hline 6 & Ketepatan penyusunan paragraf, kalimat, diksi, bentuk kata, ketepatan makna & 7,37 & 10 \\
\hline \multirow[t]{4}{*}{7} & $\begin{array}{l}\text { Ketepatan penggunaan ejaan, kerapian dan tulisan, kejelasan dan ketepatan } \\
\text { penulisan kata }\end{array}$ & 7,53 & 10 \\
\hline & Jumlah skor & 52,71 & 70 \\
\hline & Skor rata-rata & 75,30 & \\
\hline & $\begin{array}{ll}\text { Skor maksimum } & : 100 \\
\text { Perhitungan nilai skala } & : 0--100 \\
\text { Perhitungan nilai Akhir } & =(\text { Skor maksimum/Skor maksimum) } \times 100 \%\end{array}$ & & \\
\hline
\end{tabular}




\subsection{Siklus Tiga}

\section{Aktivitas Belajar Siswa}

Aktivitas siswa dalam proses pembelajaran memahami bacaan narasi melalui teknik Cooperative Integrated Reading and Composition (CIRC) masuk kategori baik dengan ketercapaian $80 \%$. Untuk lebih jelasnya perhatikan perolehan data pada tabel berikut.

Tabel 8

Rekapitulasi Hasil Pengamatan Aktivitas Belajar Siklus Tiga

\begin{tabular}{clcccc}
\hline \multirow{2}{*}{ No. } & & \multirow{2}{*}{ Ativitas Siswa dalam Pembelajaran } & \multicolumn{3}{c}{ Skor } \\
\cline { 4 - 6 } & & 38 & 38 & - & C \\
\hline 1 & Siswa tidak datang terlambat & 38 & 36 & - & 2 \\
\hline 2 & Siswa berpakaian rapih & 38 & 31 & - & 7 \\
\hline 3 & Siswa membaca dengan aktif & 38 & 29 & 4 & 5 \\
\hline \multirow{2}{*}{4} & $\begin{array}{l}\text { Siswa berinteraksi/diskusi dengan teman-teman selama } \\
\text { pembelajaran }\end{array}$ & 38 & 27 & - & 11 \\
\hline 5 & Siswa mengajukan pertanyaan & 38 & 26 & 1 & 11 \\
\hline 6 & Siswa berperan aktif dalam pembelajaran & 38 & 24 & - & 14 \\
\hline 7 & Siswa memberikan komentar atau pendapat & 38 & 28 & - & 10 \\
\hline 8 & Siswa mendiskusikan ide dengan temannya & 38 & 29 & - & 9 \\
\hline 9 & Siswa mengungkapkan ide-ide dalam pembelajaran. & 38 & 36 & - & 2 \\
\hline 10 & Siswa mengerjakan tugas tepat waktu & 380 & 304 & 5 & 71 \\
\hline & Jumlah & & & & \multirow{2}{*}{5} \\
\hline & Persentase & $100 \%$ & $80 \%$ & $1,31 \%$ & $18,69 \%$
\end{tabular}

Keterangan: $\mathrm{a}=$ Aktif $\quad \mathrm{b}=$ Cukup Aktif $\quad \mathrm{c}=$ Kurang Aktif

Diperoleh persentase hasil pengamatan aktivitas belajar siswa sebagaimana tertera pada tabel di atas dengan rincian: kategori 80\% aktif, 1,31\% kategori kurang aktif, dan 18,69\% kategori cukup aktif. Selanjutnya, data hasil pengamatan proses kerja kelompok diperoleh hasil sebagaimana tertera pada tabel berikut.

Tabel 9

Rekapitulasi Hasil Pengamatan Kerja Kelompok Siklus Tiga

\begin{tabular}{cccccc}
\hline \multirow{2}{*}{ No. } & \multirow{2}{*}{ Aspek yang Diamati } & $\sum$ & \multicolumn{3}{c}{ Skor } \\
\cline { 3 - 6 } & Kerjasama & Kelompok & Aktif & Cukup aktif & Kurang aktif \\
\hline 1 & 13 & 6 & 4 & 3 \\
\hline 2 & Tanggung jawab & 13 & 7 & 4 & 2 \\
\hline 3 & Keaktifan & 13 & 8 & 3 & 2 \\
\hline 4 & Ketelitian & 13 & 29 & 14 & 9 \\
\hline & Jumlah & 52 & $55,77 \%$ & $26,93 \%$ & $17,30 \%$ \\
\hline
\end{tabular}

Diperoleh persentase hasil pengamatan sebagaimana tertera pada Tabel 9 dengan rincian 55,77\% kategori aktif, 26,93\% kategori cukup aktif, dan 17,30\% kategori kurang aktif. Hasil pengamatan yang dilakukan oleh kolaborator tentang proses pembelajaran 
menulis narasi yang dilakukan oleh guru, diperoleh persentase hasil pengamatan masuk kategori baik, yaitu mencapai $82 \%$. Untuk lebih jelasnya perhatikan Tabel 10 berikut ini.

Tabel 10

Rekapitulasi Pengamatan Aktivitas Guru dalam Proses Pembelajaran - Siklus Tiga

\begin{tabular}{|c|c|c|c|c|c|c|c|c|}
\hline \multirow[t]{2}{*}{ No } & \multirow[b]{2}{*}{ Aktivitas Guru dalam Proses Pembelajaran } & \multicolumn{5}{|c|}{ Hasil Penilaian } & \multirow{2}{*}{$\begin{array}{l}\sum \\
\text { Skor }\end{array}$} & \multirow{2}{*}{$\begin{array}{l}\text { Skor } \\
\text { Mak }\end{array}$} \\
\hline & & A & B & $\mathrm{C}$ & $\mathrm{D}$ & $\mathrm{E}$ & & \\
\hline \multirow[t]{3}{*}{$\mathrm{I}$} & PERSIAPAN PEMBELAJARAN & & & & & & & \\
\hline & 1. Persiapan skenario pembelajaran & & 4 & & & & 4 & 5 \\
\hline & 2. Kesiapan sumber/materi yang akan diajarkan & & 4 & & & & 4 & 5 \\
\hline \multirow[t]{5}{*}{ II } & KEGIATAN PENDAHULUAN & & & & & & & \\
\hline & 1. Mengecek kehadiran siswa & & 4 & & & & 4 & 5 \\
\hline & 2. Apersepsi & & 4 & & & & 4 & 5 \\
\hline & 3. Mengemukakan tujuan pembelajaran siswa & 5 & & & & & 5 & 5 \\
\hline & 4. Menjelaskan deskripsi singkat materi Pembelajaran & & 4 & & & & 4 & 5 \\
\hline \multirow[t]{11}{*}{ III } & KEGIATAN INTI & & & & & & & \\
\hline & 1. Penguasaan materi pembelajaran & 5 & & & & & 5 & 5 \\
\hline & 2. Penguasaan kelas & & 4 & & & & 4 & 5 \\
\hline & 3. Mengarahkan keterkaitan contoh narasi dengan & & & & & & & \\
\hline & menulis narasi. & & 4 & & & & 4 & 5 \\
\hline & 4. Membimbing siswa dalam proses pembelajran & & 4 & & & & 4 & 5 \\
\hline & 5. Menggunakan bahasa yang baik dan benar & & 4 & & & & 4 & 5 \\
\hline & 6. Menggunakan bahasa yang mudah dimengerti. & & 4 & & & & 4 & 5 \\
\hline & 7. Menerapkan teknik CIRC & & 4 & & & & 4 & 5 \\
\hline & 8. Melakukan pemantauan aktivitas belajar siswa. & & 4 & & & & 4 & 5 \\
\hline & 9. Memberikan motivasi terhadap aktivitas belajar siswa & & 4 & & & & 4 & 5 \\
\hline \multirow[t]{8}{*}{ IV } & KEGIATAN PENUTUP & & & & & & & \\
\hline & 1. Melibatkan siswa dalam proses penyimpulkan & & 4 & & & & 4 & 5 \\
\hline & 2. Melakukan evaluasi & & 4 & & & & 4 & 5 \\
\hline & 3. Mengembalikan lembar tugas siswa & & 4 & & & & 4 & 5 \\
\hline & $\begin{array}{l}\text { 4. Melaksanakan remedial bagi siswa yang belum tuntas } \\
\text { KKM. }\end{array}$ & & 4 & & & & 4 & 5 \\
\hline & $\begin{array}{l}\text { 5. Memberikan tugas terkait dengan materi yang baru } \\
\text { diajarkan }\end{array}$ & & 4 & & & & 4 & 5 \\
\hline & Skor Maksimal & & & & & & 82 & 100 \\
\hline & Persentase & & & & & & $82 \%$ & \\
\hline
\end{tabular}

\section{Hasil Belajar Siswa}

Pada pertemuan siklus tiga berlangsung dalam proses pembelajaran menulis narasi melalui teknik Cooperative Integrated Reading and Composition (CIRC) telah mengalami peningkatan yang signifikan dalam menulis narasi dengan nilai rata-rata ketercapaian indikator 81,014. Jika dipersentasekan, indikator itu sudah mencapai 81\% yang berarti mengalami peningkatan dari indikator yang telah ditetapkan, yaitu $75 \%$ dari yang telah ditentukan dalam penelitian ini. Lebih jelasnya perhatikan tabel berikut. 
Tabel 11

Rekapitulasi Hasil Belajar Menulis Narasi Siswa Siklus Tiga

\begin{tabular}{|c|c|c|c|}
\hline No & Aspek yang Dinilai & Skor & Skor Mak \\
\hline 1 & Ketepatan menentukan tema narasi & 8,16 & 10 \\
\hline 2 & Ketepatan menentukan tokoh & 8,13 & 10 \\
\hline 3 & Ketepatan menentukan setting/latar & 7,84 & 10 \\
\hline 4 & Ketepan menentukan alur/plot & 7,18 & 10 \\
\hline 5 & Kalimat utama dan penjelas & 7,53 & 10 \\
\hline 6 & $\begin{array}{l}\text { Ketepatan penyusunan paragraf, kalimat, diksi, bentuk kata, ketepatan } \\
\text { makna }\end{array}$ & 7,54 & 10 \\
\hline 7 & $\begin{array}{l}\text { Ketepatan penggunaan ejaan, kerapian dan tulisan, kejelasan dan } \\
\text { ketepatan penulisan kata }\end{array}$ & 7,53 & 10 \\
\hline & Jumlah skor & 56,71 & 70 \\
\hline & Skor rata-rata & 81,014 & \\
\hline & $\begin{array}{ll}\text { Skor maksimum } & : 100 \\
\text { Perhitungan nilai skala } & : 0--100 \\
\text { Perhitungan nilai Akhir } & =\text { (Skor maksimum/Skor maksimum) x 100\% }\end{array}$ & & \\
\hline
\end{tabular}

Sebanyak 30 siswa $(81,08 \%)$ yang dikategorikan tuntas dan telah mencapai lebih dari $75 \%$ dari indikator yang telah ditetapkan dalam penelitian ini dari jumlah 37 anak, sedangkan yang tidak tuntas dalam belajar sebanyak 7 siswa (18,92\%). Untuk lebih jelasnya, data tersebut dapat dilihat pada tabel berikut.

Tabel 12

Rekapitulasi Ketuntasan Hasil Belajar Siswa

Siklus Tiga

\begin{tabular}{cccccccc}
\hline No. & \multirow{2}{*}{ KKM } & $\begin{array}{c}\text { Rentang } \\
\text { Nilai }\end{array}$ & $\Sigma$ Siswa & Persentase & \multicolumn{2}{c}{ Katagori } \\
\cline { 1 - 5 } 1 & \multirow{2}{*}{67} & $0-66$ & 7 & $18,92 \%$ & - & Tuntas & Tidak Tuntas \\
\cline { 4 - 7 } & & $67-100$ & 30 & $81,08 \%$ & $\sqrt{ }$ & - \\
\hline
\end{tabular}

Berdasarkan data tersebut di atas rata-rata nilai setiap aspek ada peningkatan dari menulis narasi. Jadi, nilai rata-rata untuk keseluruhan komponen menulis narasi yang dicapai siswa telah mencapai indikator minimal yang telah diharapkan dalam penelitian ini sesuai dengan KKM SMPN 3 Natar adalah 67. Sedangkan perolehan hasil pada siklus tiga siswa kelas VII/F sudah mencapai rata-rata 81,014 dan yang telah mencapai KKM sebanyak 30 siswa, dengan demikian ketuntasan belajarnya mencapai 81\% (37 siswa), karena ada 1 (satu) anak izin tidak masuk sekolah.

\section{Pembahasan Hasil Pembelajaran}

Proses menulis sebagaimana dijelaskan pada bab terdahulu, merupakan suatu proses untuk menyampaikan pikiran, angan-angan, perasaan dalam bentuk simbol atau 
tanda tulisan yang memiliki makna. Dalam kegiatan menulis terdapat suatu kegiatan merangkai, menyusun, melukiskan suatu lambang atau tulisan berupa kumpulan huruf yang membentuk kata, kumpulan kata yang membentuk frasa atau kalimat, kumpulan kalimat yang membentuk paragraf, dan kumpulan paragraf yang membentuk wacana atau karangan yang memiliki makna.

2.1 Aktivitas Siswa dan Guru

Dalam kaitannya proses menulis dengan proses pelaksanaan pembelajaran, salah satunya dengan meningkatkan kemampuan menulis melalui teknik Cooperative Integrated Reading and Composition (CIRC) yang dapat meningkatkan aktivitas siswa dalam pembelajaran. Sebagaimana terlihat pada Diagram 1 berikut.

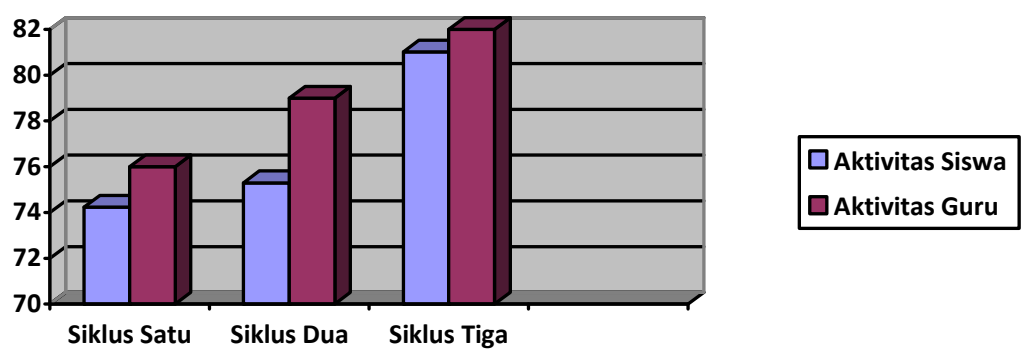

Diagram 1. Skor Rata-Rata Aktivitas Siswa dan Guru

Pada siklus satu aktivitas siswa mendapat skor 74,24 (lihat Tabel 3) dan aktivitas gurunya memperoleh skor 76 (lihat Tabel 2) dan pada siklus dua aktivitas siswa mengalami peningkatan dengan skor rata-rata 75,30 (lihat Tabel 7), sedangkan aktivitas gurunya memperoleh skor rata-rata 79 (lihat Tabel 6). Pada siklus tiga yang sudah terlaksana dengan baik, dengan data yang dapat dilihat pada aktivitas belajar siswa yang mendapat skor rata 81,014 (lihat Tabel 11) dan aktivitas guru memperoleh skor rata-rata 82 (lihat Tabel 10).

\subsection{Proses Evaluasi Pembelajaran}

Pada siklus satu guru mengalami kesulitan dalam melakukan penilaian disebabkan belum terbiasa dengan menggunakan rubrik penilaian menulis narasi. Akan tetapi pada kegiatan siklus dua dan siklus tiga guru semakin paham di dalam mengevaluasi kemampuan menulis narasi siswa. Perhatikan Diagram 2 berikut yang memperlihatkan nilai skor kemampuan menulis siswa. Data yang terlihat pada diagram berikut menunjukkan bahwa pada siklus satu mendapat skor rata-rata 74,24 (lihat Tabel 
3), siklus dua mendapat skor rata-rata 75,30 (lihat Tabel 7), dan pada siklus tiga mendapat skor rata-rata 81,014 (lihat Tabel 11 ).

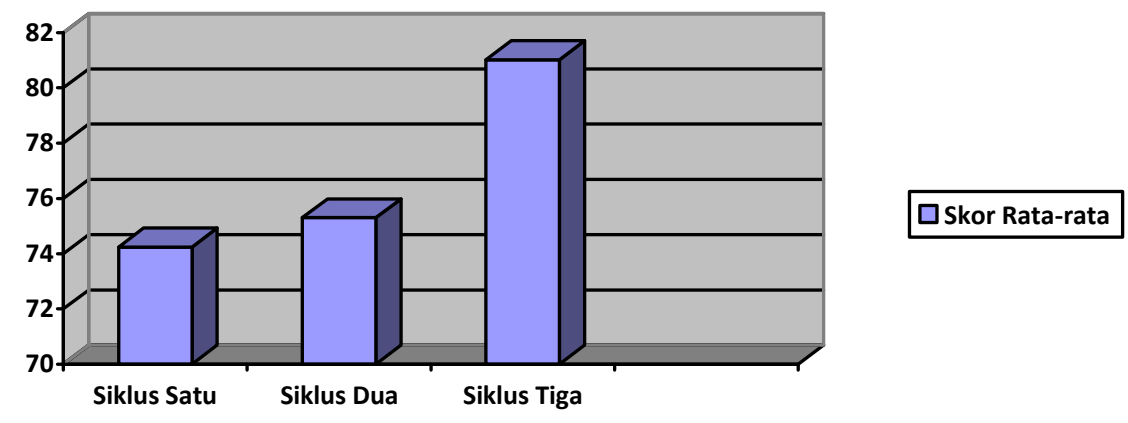

Diagram 2. Nilai Rata-Rata Kemampuan Menulis Siswa

\subsection{Kemampuan Menulis dan Ketuntasan Belajar Siswa}

Penilaian terhadap kriteria ketuntasan minimal yang telah ditetapkan di SMP Negeri 3 Natar, yaitu KKM 67. Kemampuan menulis narasi siswa kelas VII/F mengalami peningkatan dari siklus satu ke siklus dua, dari siklus dua ke siklus tiga telah dapat mencapai KKM yaitu 67. Peningkatan nilai kemampuan menulis narasi siswa meningkat pada siklus satu sampai siklus tiga adalah 72,24, 75,30, dan 81,014. Untuk persentase ketuntasan belajarnya dari siklus satu 65\% dari 38 anak, siklus dua 73,68\% dari 38 anak, dan siklus tiga mencapai $81 \%$ dari 37 siswa, 1 anak izin tidak masuk. Untuk lebih jelasnya perhatikan diagram berikut.

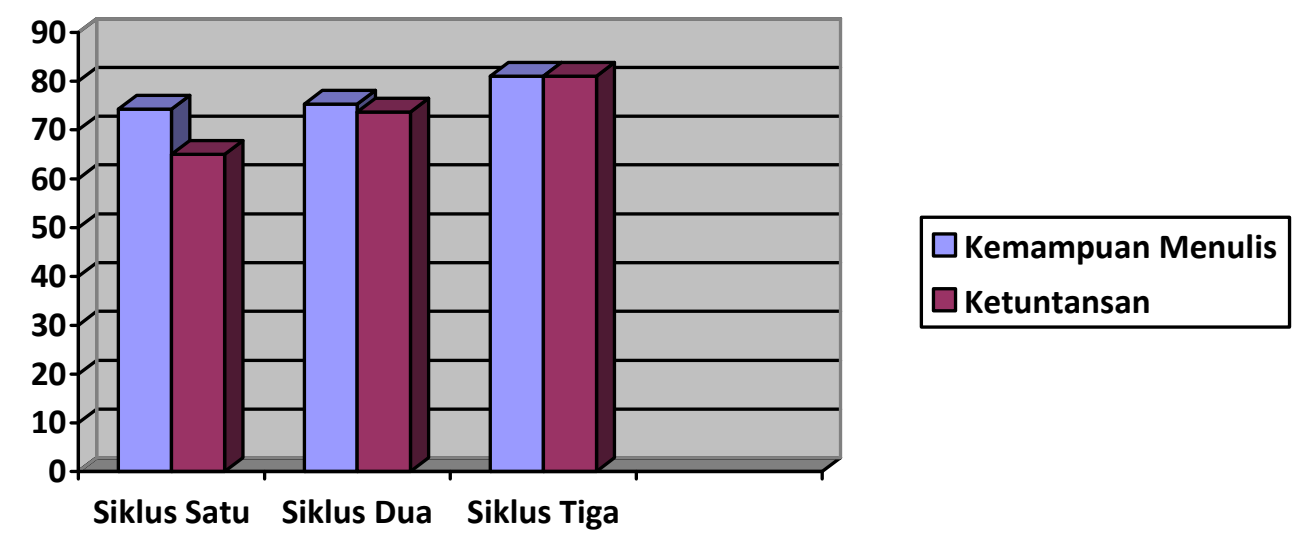

Diagram 3. Nilai Rata-Rata Kemampuan Menulis dan Persentase Ketuntasan Belajar

Pada siklus satu nilai rata-rata untuk keseluruhan komponen menulis narasi yang dicapai siswa sudah mencapai indikator yang diharapkaan sesuai dengan standar KKM 
di SMP Negeri 3 Natar, yaitu 67 dan ketuntasan belajar 75\% dari jumlah per kelas. Akan tetapi, dari aspek ketuntasan belajar belum tercapai karena baru mencapai $65 \%$. Pada siklus satu ini siswa memperoleh nilai rata-rata 74,24. Siswa yang mencapai KKM berjumlah 25 orang sehingga persentase ketuntasan belajar memperoleh $65 \%$ dari 38 siswa.

Pada siklus dua nilai rata-rata untuk keseluruhan komponen menulis narasi yang dicapai siswa sudah mencapai indikator yang diharapkan dalam penelitian ini sesuai dengan standar KKM di SMPN 3 Natar, yaitu 67, tetapi dari aspek ketuntasan belajar belum tercapai karena baru mencapai 73,68\%. Pada siklus dua ini siswa memperoleh nilai rata-rata 75,30. Siswa yang mencapai KKM berjumlah 28 orang sehingga persentase ketuntasan belajar memperoleh $73,68 \%$ dari 38 siswa.

Pada siklus tiga nilai rata-rata untuk keseluruhan komponen menulis narasi yang dicapai siswa sudah ada peningkatan dan mencapai indikator yang diharapkaan. Pada siklus tiga ini siswa memperoleh nilai rata-rata 81,014. Siswa yang mencapai KKM berjumlah 30 orang sehingga persentase ketuntasan belajar memperoleh $81 \%$ dari 37 siswa, 1 siswa tidak masuk karena izin.

\section{PENUTUP}

Berdasarkan hasil penelitian dan pembahasan penelitian tindakan kelas di SMPN 3 Natar, Kabupaten Lampung Selatan, dapat disimpulkan sebagai berikut. (1) Pada siklus satu proses pelaksanaan pembelajaran belum berjalan lancar ada beberapa siswa masih bingung dan guru belum maksimal dalam membimbing pelaksanaan pembelajaran; (2) Pada siklus dua pelaksaan pembelajaran mulai berjalan lancar guru dalam membimbing siswa sudah maksimal; dan (3) Pada siklus tiga proses pembelajaran sudah dapat berjalan dengan baik pada kegiatan diskusi siswa sudah maksimal karena siswa sudah dapat berpikir dengan baik.

Hasil evaluasi kemampuan menulis narasi siswa mengalami peningkatan dari siklus satu ke siklus dua, dari siklus dua ke siklus tiga telah dapat mencapai KKM yang ditetapkan sekolah, yaitu 67. Peningkatan nilai kemampuan menulis narasi siswa kelas VII/F siklus satu sampai tiga adalah 74,24; 75,30; dan 81,014 serta persentase ketuntasan belajar siswa dari siklus satu sampai tiga adalah $65 \%, 73 \%$, dan $81 \%$. 


\section{DAFTAR PUSTAKA}

Akhadiah, S. dkk. (1997). Pembinaan Kemampuan Menulis Bahasa Indonesia. Jakarta: Erlangga.

Apriyanti, E. (2010). Penerapan Aneka Sumber Belajar untuk Meningkatkan Kemampuan Menulis Siswa Pada Pembelajaran. Bahasa Indonesia di SMPN. Universitas Lampung.

Dalman. (2012). Keterampilan Menulis. Jakarta: Raja Grafindo Perkasa Aditama. Depdiknas. (1999). Kamus Besar Bahasa Indonesia (KBBI). Jakarta: Depdikbud.

Finoza, L. (2008). Komposisi Bahasa Indonesia. Jakarta: Insan Mulia.

Kalidjernih, F. K. (2010). Penulisan Akademik. Bandung: Widya Aksara Press.

Keraf, G. (2003). Argumentasi dan Narasi. Jakarta: Gramedia.

Pramita, Puri. (2015). Retorika Dakwah Yusuf Mansur dan Pemanfaatannya sebagai Bahan Ajar Berbicara dalam Bentuk CN Interaktif untuk Siswa SMA. Ranah: Jurnal Kajian Bahasa, 4 ( 2). https://doi.org.10.26499/rnh.v4i2.28

Rusman. (2012). Model-Model Pembelajaran. Jakarta: Raja Grafindo Persada.

Rusyana, Y. (1994). Bahasa dan Sastra dalam Gamitan Pendidikan. Bandung: Diponegoro.

Setiyadi, A. B. (2006). Metode Penelitian Pengajaran Bahasa Asing. Yogyakarta: Graha Ilmu.

Slavin, R. Y. (2005). Cooperative Learning.Terjemahan. Bandung: Nusa Indah.

Suparno dan Yunus. (2003). Keterampilan Dasar Menulis. Jakarta: Pusat Penerbitan Universitas Terbuka.

Tarigan, H. G. (1998). Menulis sebagai Keterampilan Berbahasa. Bandung: Angkasa. 